\title{
Uranium Removal from Groundwater and Wastewater Using Clay-Supported Nanoscale Zero-Valent Iron
}

\author{
Borys Kornilovych ${ }^{1,2, *}$, Iryna Kovalchuk ${ }^{2}$, , Viktoriia Tobilko $^{1}$ and Stefano Ubaldini ${ }^{3}$ (I) \\ 1 National Technical University of Ukraine "Igor Sikorsky Kyiv Polytechnic Institute”, 37 Peremogy Av., \\ 03056 Kyiv, Ukraine; vtobilko@gmail.com \\ 2 Institute for Sorption and Problems of Endoecology, National Academy of Science of Ukraine, 13 General \\ Naumov Str., 03164 Kyiv, Ukraine; kowalchukiryna@gmail.com \\ 3 Istituto di Geologia Ambientale e Geoingegneria, CNR, Area della Ricerca di Roma RM 1-Montelibretti-Via \\ Salaria Km 29,300—Monterotondo Stazione, 00015 Roma, Italy; stefano.ubaldini@igag.cnr.it \\ * Correspondence: b.kornilovych@gmail.com; Tel.: +38-050-8407970
}

Received: 17 September 2020; Accepted: 23 October 2020; Published: 26 October 2020

check for updates

\begin{abstract}
The peculiarities of sorption removal of uranium (VI) compounds from the surface and mineralized groundwater using clay-supported nanoscale zero-valent iron (nZVI) composite materials are studied. Representatives of the main structural types of clay minerals are taken as clays: kaolinite $(\mathrm{Kt})$, montmorillonite (MMT) and palygorskite $(\mathrm{Pg})$. It was found that the obtained samples of composite sorbents have much better sorption properties for the removal of uranium from surface and mineralized waters compared to natural clays and nZVI.It is shown that in mineralized waters uranium (VI) is mainly in anionic form, namely in the form of carbonate complexes, which are practically not extracted by pure clays. According to the efficiency of removal of uranium compounds from surface and mineralized waters, composite sorbents form a sequence: montmorillonite-nZVI > palygorskite-nZVI > kaolinite-nZVI, which corresponds to a decrease in the specific surface area of the pristine clay minerals.
\end{abstract}

Keywords: uranium; clays; nanoscale zero-valent iron; groundwater; wastewater

\section{Introduction}

Pollution of the water basin in sites where uranium ore is mined and processed is one of the most important environmental problems, requiring an effective and rational solution [1]. The sources of surface and groundwater pollution are, first of all, the areas of development of uranium deposits, storages of wastes from hydrometallurgical processing of uranium ores, sites where uranium where enriched [2-4]. Water pollution with uranium compounds is often accompanied by pollution of other toxic elements, for example, arsenic [5].

Contaminated groundwater in places of extraction and processing of uranium ores, in addition to the high content of compounds, is characterized by high mineralization. The latter is a few grams per litre, mainly due to sulfates of $\mathrm{Ca}$ and $\mathrm{Mg}$, which are formed due to the use of sulfuric acid in the technological processes of leaching [6]. In such waters, it is mainly in the composition of negatively charged sulfate or carbonate complexes, which significantly complicates the processes of water purification [7].

Sorption methods using ion exchange resins and synthetic inorganic sorbents are most widely used for deep purification of sewage and surface waters from uranium complexes [8-10]. At the same time, if it is necessary to treat large amounts of treated water, the economic factor becomes principal.

Some of the new effective environmental protection technologies that havebeen developed and widely tested in recent years are technologies based on the use of highly reactive nanoscale zero-valent 
iron. The use of coarsely dispersed zero-valent iron is quite common in environmental practice in the construction of permeable reaction barriers that are installed in the path of contaminated groundwater and serve as a collector of various toxicants [11,12]. The advantage of using nZVI is the possibility of its use for groundwater purification without the application of permeable reaction barriers, the construction of which requires significant capital costs.

Suspensions based on nZVI can be pumped into the ground along the path of groundwater directly in front of contaminated areas. Further, they are carried with underground streams, promoting the decomposition of organic toxicants or sorption of inorganic pollutants on themselves.

The first successful results on the use of nZVI were obtained during the decomposition of organic toxicants (chlorinated solvents, pesticides, dyes) $[13,14]$. Subsequently, the effectiveness of this technology was shown for a variety of inorganic pollutants, including heavy metals [15] and natural radionuclides [16,17]. However, the potential risks for natural ecosystems when using nZVI is insufficiently studied so far [18].

The problem with the use of nZVI for in situ and ex situ technologies is the insufficient colloidal stability of its suspensions, easy aggregation, and difficulty in separating nZVI from the treated solution. To solve it, various polymers and surfactants are commonly used $[19,20]$. Another approach to increase the stability of suspensions is their anchoring onto a solid matrix, which allows not only to increase their stability and stability to oxidation, but also to expand the scope of their application in traditional sorption technologies [21]. Active carbons [22], amorphous silica [23,24], layered double hydroxides [25], carbonized fungi [26], graphene and composites based on it [27,28] and others were successfully investigated.

Some of the most widely used matrices as the supports of nZVIare clay minerals, which have a significant specific surface area and rather high sorption properties in relation to radionuclides and heavy metal ions $[29,30]$. Iron-containing composite sorbents based on clays have enhanced sorption characteristics in relation to heavy metals and radionuclides compared to the initial minerals [31]. Representatives of almost all major classes of clay minerals were studied as matrixes: kaolinite [32], montmorillonite [33,34], illite [35], palygorskite [36].

While considerable experimental material accumulated on the purification of uranium-containing water using nZVI, there was no comparative study of the sorption properties of iron-containing composites of different composition based on clay minerals. Taking into account the importance of environmental studies based on natural minerals, the removal of uranium by nZVI supported on kaolinite, montmorillonite and palygorskite was investigated, including the removal efficiency of uranium from contaminated groundwater with low and high mineralization.

\section{Materials and Methods}

The object of the study was a layer silicate kaolinite $\left(\mathrm{Al}_{4} \mathrm{Si}_{4} \mathrm{O}_{10}(\mathrm{OH})_{8}\right)$ with a structure of 1:1 type. This clay was taken from the Glukhovets deposit (Ukraine), and has the most perfect crystal structure among the kaolinites from other numerous kaolin deposits of Ukraine. Among the representatives of layered silicates with a 2:1 structure (smectites), montmorillonite from the Cherkassk deposit (Ukraine) with a structural formula $\left(\mathrm{Ca}_{0.12} \mathrm{Na}_{0.03} \mathrm{~K}_{0.03}\right)_{0.18}\left(\mathrm{Al}_{1.39} \mathrm{Mg}_{0.13} \mathrm{Fe}_{0.44}\right)_{1.96}\left(\mathrm{Si}_{3.88} \mathrm{Al}_{0.12}\right)_{4.0} \mathrm{O}_{10}(\mathrm{OH})_{2} \times \mathrm{nH}_{2} \mathrm{O}$ was chosen. Fibrous clay mineral palygorskite (also known as attapulgite) with a structural formula $\mathrm{Mg}_{5} \mathrm{Si}_{8} \mathrm{O}_{20}(\mathrm{OH})_{2} \times 4 \mathrm{H}_{2} \mathrm{O}$ was also taken from the Cherkassk deposit (Ukraine).

The purification of natural minerals from impurities of quartz, feldspars, carbonates, aluminium and iron oxides was carried out.X-ray powder diffraction (XRD) patterns were recorded on X-ray diffractometer DRON-4-07 (Russia) in the range of $2-40^{\circ}(2 \theta)$ using CuK $\alpha$ irradiation.

The parameters of the porous structure: specific surface area (SSA), total pore volume (V), average pore radius ( $\mathrm{r}$ ) of the natural and composite sorbents were determined by the BET method from nitrogen adsorption isotherms obtained on a Nova 2200e gas analyzer (USA), pore distribution(Rmax)—by BJH and DFT methods [37]. 
To obtain composite sorbents "clay mineral/nZVI" with a mass ratio nZVI: clay mineral 0.2: 1 modified method was used [38,39]. To do this, in a $0.2 \mathrm{M}$ solution of $\mathrm{Fe}\left(\mathrm{NO}_{3}\right)_{3} \cdot 9 \mathrm{H}_{2} \mathrm{O}$, weighed clay was introduced.The resulting suspension ( $\mathrm{pH} 2$ ) was quantitatively transferred to a three-necked flask and the ion $\mathrm{Fe}^{3+}$ reduction process was performed with a solution of sodium borohydride $\left(\mathrm{NaBH}_{4}\right)$ in a nitrogen atmosphere. The resulting composite sorbent was then separated from the liquid phase by centrifugation and washed three times with alcohol. The resulting precipitate was dried under vacuum at a temperature of $60^{\circ} \mathrm{C}$ and crushed to obtain a fraction $\leq 0.1 \mathrm{~mm}$.

Water purification from uranium ions was performed using natural clay minerals and composite sorbents. Solutions were prepared with distilled water and uranyl trihydrosulfate salt $\left(\mathrm{UO}_{2} \mathrm{SO}_{4} \cdot 3 \mathrm{H}_{2} \mathrm{O}\right)$. $1 \mathrm{M} \mathrm{NaCl}$ solution to create ionic strength ( 0.01) was used. The $\mathrm{pH}$ of the solutions was adjusted with $0.1 \mathrm{M}$ solutions $\mathrm{NaOH}$ and $\mathrm{HCl}$.

Mineralized waters were used solutions, whose composition corresponded to the composition of underground mineralized water near the liquid waste storage facility for hydrometallurgical processing uranium ores at the Centre of Ukrainian Uranium Industry (Zhovti Vody) by anions: $\mathrm{HCO}_{3}^{-}-450$; $\mathrm{Cl}^{-}-180 ; \mathrm{SO}_{4}^{2-}-2830 ; \mathrm{NO}_{3}^{-}-130 \mathrm{mg} / \mathrm{l}$ and by cations: $\mathrm{Ca}^{2+}-576 ; \mathrm{Mg}^{2+}-209 ;\left(\mathrm{Na}^{+}+\mathrm{K}^{+}\right)-391$; $\mathrm{NH}_{4}^{+}-0.92 ; \mathrm{Ni}^{2+}-<0.05 ; \mathrm{Cu}^{2+}-<0.03 ; \mathrm{Co}^{2+}-<0.06 ; \mathrm{Mn}_{\text {sum }}-0.10 ; \mathrm{Zn}^{2+}-<0.01 ; \mathrm{Pb}^{2+}-<0.19$; $\mathrm{Cd}^{2+}-<0.01 ; \mathrm{Fe}_{\text {sum }}-0.05 \mathrm{mg} / \mathrm{L}$ [40]. The output solutions were prepared on the basis of the corresponding sodium salts, the total salt content was- $5280 \mathrm{mg} / \mathrm{L}, \mathrm{pH} 7.2$.

Sorption of uranium ions was performed under static conditions at room temperature with continuous shaking of the samples for $1 \mathrm{~h}$ (the volume of the aqueous phase- $50 \mathrm{~mL}$, the amount of sorbent- $0.1 \mathrm{~g})$. Inthe end, the liquid phase was separated by centrifugation (6000 rpm) and the equilibrium metal concentration was determined spectrophotometrically (UNICO 2100UV) using an Arsenazo III reagent at a wavelength of $665 \mathrm{~nm}$.

\section{Results}

X-ray analysis of samples shows the presence of only small impurities in pristine minerals (Figure 1).

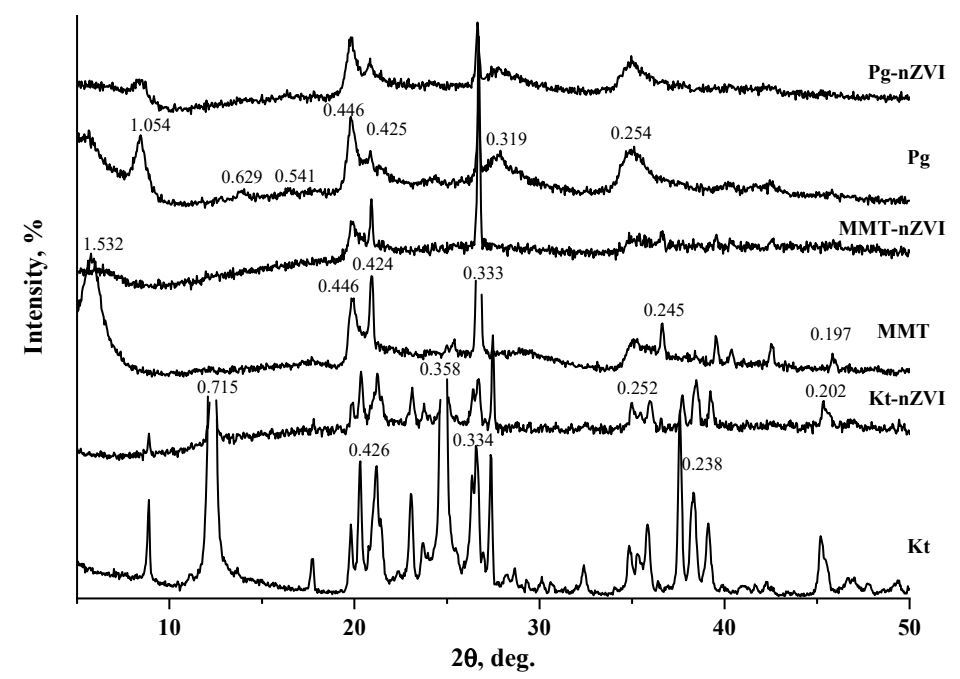

Figure 1. X-ray powder diffraction (XRD) patterns of pristine and nanoscale zero-valent iron (nZVI)—modified clay minerals.

On diffractograms (XRD) of all modified minerals, there are weak reflections at 0.252 and $0.202 \mathrm{~nm}$ corresponding to crystalline phases of zero-valent iron $(\alpha-\mathrm{Fe})$, iron oxide $(\mathrm{FeO})$, and also, in time, smaller quantities of goethite $(\mathrm{FeOOH})$. Clays kept their structures in mixtures, since no structural changes between neat and supported clays were found.The amount of iron applied to the surface 
is, according to the chemical analysis of the solution after treatment of the modified samples with hydrochloric acid, $0.17 \mathrm{mg} / \mathrm{g}$ for all minerals.

By nature, the nitrogen sorption isotherm on the pristine kaolinite (Figure 2), according to the modified de Boer classification, belongs to type II (b) isotherms and are typical for nonporous sorbents with a small macroporous component [41].

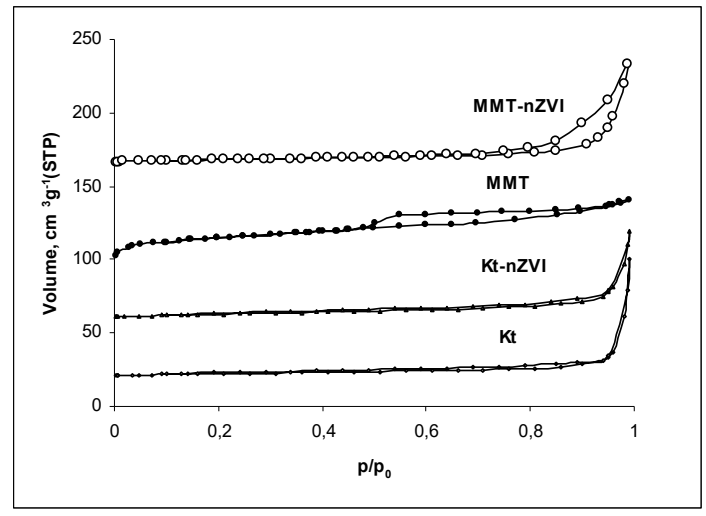

(a)

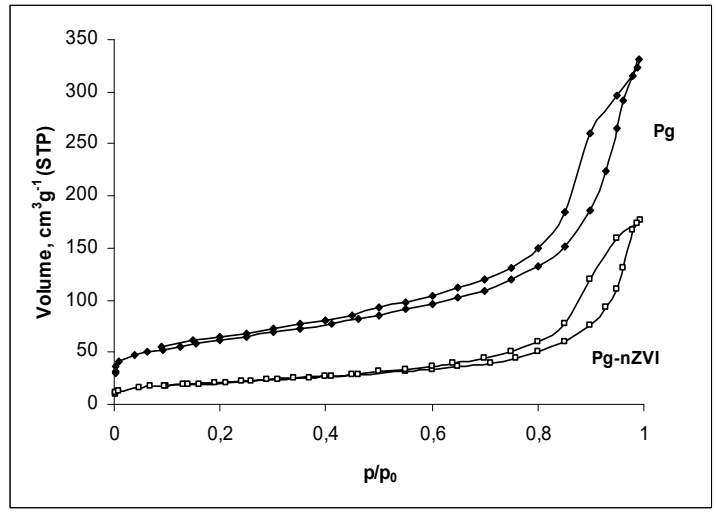

(b)

Figure 2. Nitrogen adsorption-desorption isotherms of pristine and nZVI-modified clay minerals:

(a) - kaolinite and montmorillonite,(b) - palygorskite.

The narrow hysteresis loop of type $\mathrm{H} 3$ on isotherms is the result of capillary condensation in the structural aggregates of kaolinite between weakly interconnected flat elementary packages of the mineral. The nature of the nitrogen adsorption curves on the samples of montmorillonite and paligorskite are similar to kaolinite and, thus, also belong to type II (b) isotherms with a hysteresis loop type H3. The calculated characteristics of the porous structure of the samples are given in Table 1. As can be seen from the nitrogen isotherms, the specific surface area of samples sharply decreases after the surface modification. Such reduction is stipulated by aggregation processes of small clay particles by nZVI and practically complete closing of micropores with nZVI films and the resultant blocking of the access of nitrogen molecules to these pores.

Table 1. Characteristics of the porous structure of the samples.

\begin{tabular}{|c|c|c|c|c|c|c|c|c|}
\hline \multirow{3}{*}{ Sample } & \multirow{3}{*}{$\mathrm{S}, \mathrm{m}^{2} / \mathrm{g}$} & \multirow{3}{*}{$\mathrm{V}_{\sum^{\prime}}, \mathrm{cm}^{3} / \mathrm{g}$} & \multirow{3}{*}{$\mathrm{V}_{\mu}, \mathrm{cm}^{3} / \mathrm{g}$} & \multirow{3}{*}{$\mathrm{V}_{\mu \%}, \%$} & \multicolumn{4}{|c|}{ Distribution of Pore Size, $\mathrm{nm}$} \\
\hline & & & & & \multicolumn{2}{|c|}{ BJH dV (r) } & \multicolumn{2}{|c|}{ DFT dV (r) } \\
\hline & & & & & $\mathbf{r}_{1}$ & $\mathbf{r}_{2}$ & $\mathbf{r}_{1}$ & $\mathbf{r}_{2}$ \\
\hline Kaolinite & 8.98 & 0.124 & 0.003 & 2.1 & - & - & 2.36 & $4.91-8.58$ \\
\hline Kaolinite-nZVI & 11.72 & 0.093 & 0.003 & 3.1 & - & - & 2.51 & $2.63-3.52$ \\
\hline Montmorillonite & 89.11 & 0.081 & 0.016 & 19.8 & 1.41 & - & 1.91 & 2.82 \\
\hline Montmorillonite-nZVI & 24.74 & 0.384 & 0.008 & 2.1 & 2.11 & - & 2.84 & 8.96 \\
\hline Palygorskite & 213.15 & 0.512 & 0.084 & 16.6 & 1.90 & 6.26 & - & - \\
\hline Palygorskite-nZVI & 71.68 & 0.274 & 0.002 & 0.8 & 8.89 & - & 6.73 & $8.64-9.95$ \\
\hline
\end{tabular}

Sorption $(q, \mu \mathrm{mol} / \mathrm{g})$ of uranium ions on pristine and modified samples are shown in Figure 3. On the kaolinite surface, sorption can occur on active centres of two types: ditrigonal siloxane wells on the basal surfaces of kaolinite particles and hydroxyl groups on broken bonds in tetrahedral (Si-O-Si) and octahedral (Al-O-Al) sheets on edge surfaces of the particles [42]. 


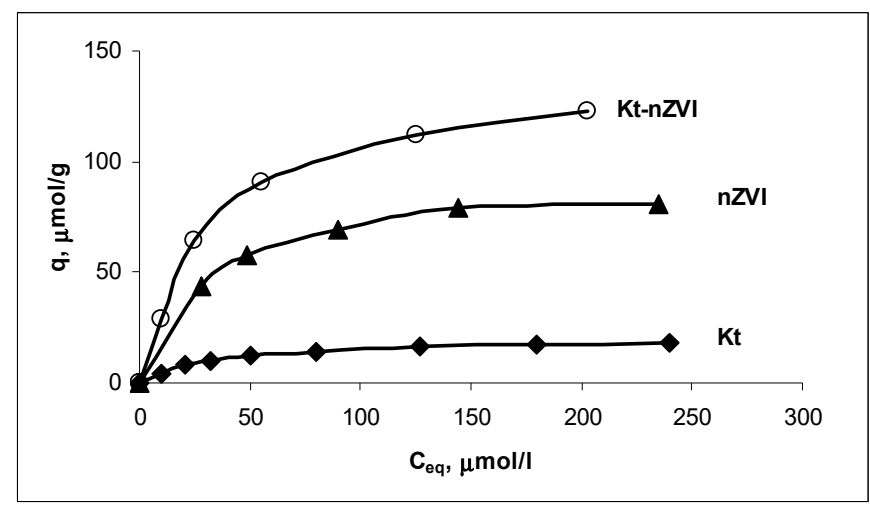

Figure 3. Sorption isotherms of $\mathrm{U}(\mathrm{VI})$ ions on pristine kaolinite and kaolinite-nZVI.

However, for the pristine Glukhovets kaolinite, due to its perfect structure and the absence of heterovalent isomorphic substitutions in the mineral structure, the charge of the structural packages is close to zero and, therefore, sorption at low concentrations of uranium ions in solution occurs mainly on hydroxyl groups located on edge surfaces of the particles.

Such sorption centres on the edge surfaces, depending on the $\mathrm{pH}$ of the medium, can have the composition $>\mathrm{Si}-\mathrm{OH}$ and $>\mathrm{Si}-\mathrm{O}^{-}$on the broken tetrahedral sheet of the mineral and $>\mathrm{Al}-\mathrm{OH}_{2}{ }^{+}$; $\mathrm{Al}-\mathrm{OH}$ and $>\mathrm{Al}-\mathrm{OH}^{-}$on a broken octahedral sheet of the mineral and sorption of uranium ions on the surface occurs with the formation of strong inner-sphere surface complexes.

The results obtained for the modified samples indicate that the sorption values of uranium ions at $\mathrm{pH} 6$ are several times higher than those for the pristine minerals (Figure 3). As it was established, synthesized nZVI has a core-shell structure and the thin film on the surface of the particles consists of iron oxides such as $\mathrm{FeO}, \mathrm{Fe}_{2} \mathrm{O}_{3}$ and $\mathrm{Fe}_{3} \mathrm{O}_{4}$ and its hydroxides [14,17,43,44]. $\mathrm{Fe}(0)$ is in the centre of the particles. As a result of such composite structure, the removal of uranium (VI) from water by nZVI is also may be affected by the redox transformation of a highly soluble form of $\mathrm{U}(\mathrm{VI})$ to less soluble $\mathrm{U}(\mathrm{IV})$ with direct electron transfer at the $\mathrm{Fe}(0)$ surface $[16,17,45]$ :

$$
\mathrm{Fe}^{0}+1.5 \mathrm{UO}_{2}{ }^{2+}+6 \mathrm{H}^{+}=\mathrm{Fe}^{3+}+1.5 \mathrm{U}^{4+}+3 \mathrm{H}_{2} \mathrm{O}
$$

In order to elucidate the synergetic effect for the Kt-nZVI composite sorbents, the removal of U(VI) by nZVI alone was also investigated. As shown in Figure 3, the removal efficiencies of U(VI) by nZVI alone wassignificantly lower than that of Kt-nZVI.

The dependence of the sorption values of uranium ions on the surface of kaolinite particles from pHis presented in Figure 4. The corresponding curves have a characteristic form with a marked minimum in the acidic and alkaline $\mathrm{pH}$ areas.

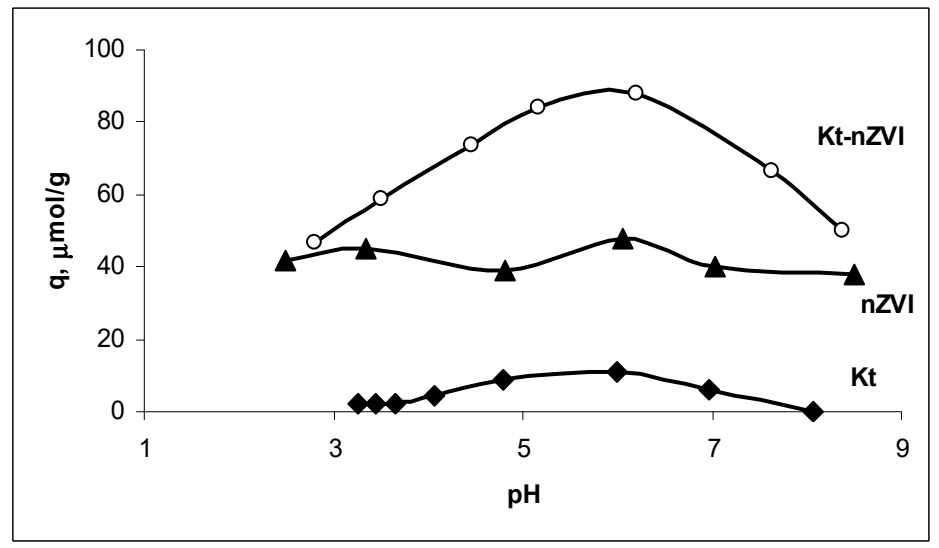

Figure 4. Sorption of $\mathrm{U}(\mathrm{VI})$ ions on pristine kaolinite and kaolinite-nZVI as a function of $\mathrm{pH}$. 
The last is due to the peculiarities of the chemistry of the clay surface and the complex chemistry of aqueous solutions of uranium salts [46]. In the acidic $\mathrm{pH}$ area, the sorption characteristics of clays in relation to uranyl cations $\mathrm{UO}_{2}{ }^{2+}$ are determined by the neutral and positive surface charge resulting from protonation of surface groups and the formation of $>>\mathrm{Si}-\mathrm{OH},>\mathrm{Al}-\mathrm{OH}$ and $>\mathrm{Al}-\mathrm{OH}_{2}{ }^{+}$groups. In the alkaline area, dissociated $>\mathrm{Si}^{-} \mathrm{O}^{-}$and $>\mathrm{Al}^{-} \mathrm{O}^{-}$groups predominate on the clay surface, and uranium in solution exists mainly in the form of neutral $\mathrm{UO}_{2}(\mathrm{OH})_{2}, \mathrm{UO}_{2} \mathrm{CO}_{3}$ and negatively charged species $\left(\mathrm{UO}_{2}\right)_{2} \mathrm{CO}_{3}(\mathrm{OH})_{3}{ }^{-}[7,47]$. This causes insignificant values of sorption of uranium compounds in these $\mathrm{pH}$ areas, because positively charged uranium species which predominated in the acidic $\mathrm{pH}$ areas are not adsorbed onto the positively charged clay surface, and negatively charged uranium species in the alkaline $\mathrm{pH}$ areas are not adsorbed onto the negatively charged clay surface. In the neutral $\mathrm{pH}$ area, the charge of the kaolinite surface and the charge of uranium ions have opposite signs, which influences the proceedings of sorption processes and the appearance of maximum on the curves of the dependence of sorption values from $\mathrm{pH}$.

Montmorillonite has a labile structure with the possibility of significant expansion of the inter-package distance during the penetration of polar water molecules between flat structural packages. This determines the availability for ion exchange processes not only of the outer but also of the inner surface of the particles of this clay mineral, which determines a significant increase in the sorption of uranium ions compared to kaolinite (see Figure 5). The nature of the dependence of sorption values from $\mathrm{pH}$ for montmorillonite corresponds to that for kaolinite, however, is less pronounced (see Figure 6). This is due to the smaller relative contribution of the edge surfaces of this mineral to its total specific surface area and the increased role of sorption centres on the basal surfaces of particles (ditrigonal wells) whose behavior is independent of $\mathrm{pH}$ [42].

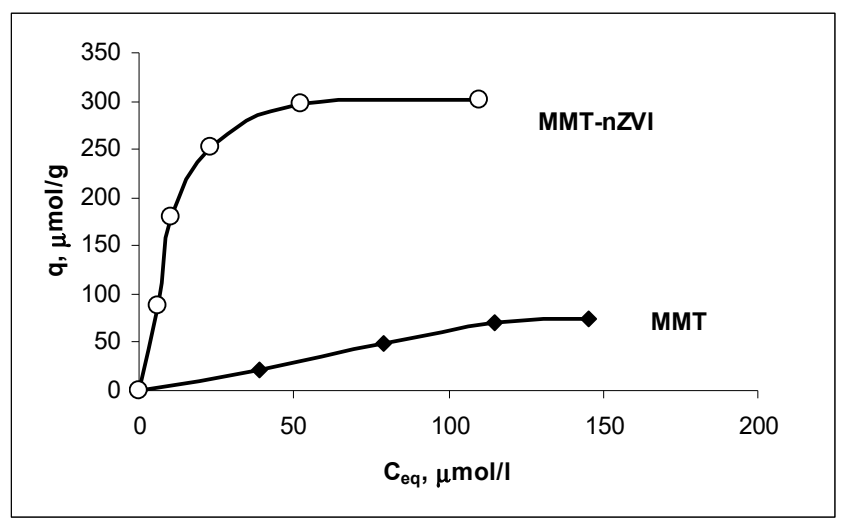

Figure 5. Sorption isotherms of U(VI) ions on pristine montmorillonite and montmorillonite-nZVI.

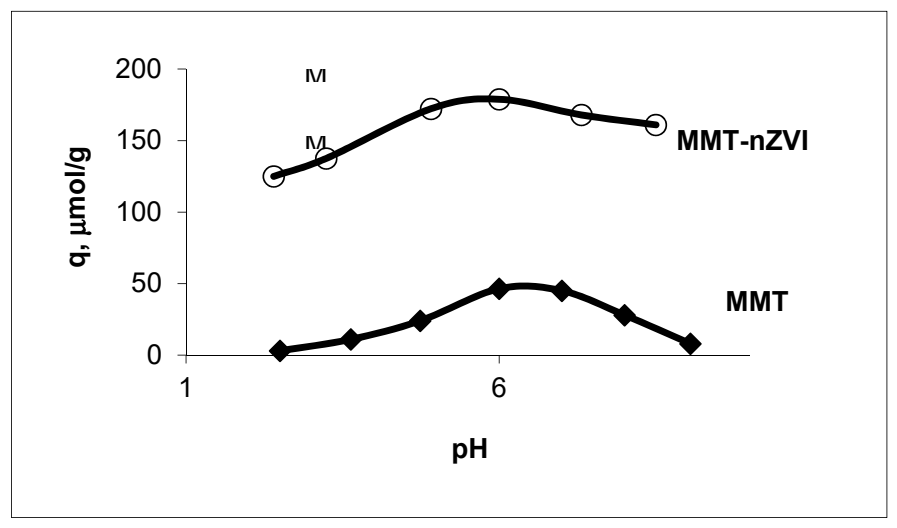

Figure 6. Sorption of U(VI) ions on pristine montmorillonite and montmorillonite-nZVI as a function of $\mathrm{pH}$. 
Particles of chain silicate paligorskite have an elongated rod-like shape, the volume of which is pierced by zeolite-like channels [48]. Sorption of ions occurs on the outer surface of the mineral, the value of which is greater than that of kaolinite and montmorillonite established by $\mathrm{N}_{2}$ sorption. However, montmorillonite particles show an outstanding property to delaminate into individual silicate layers or thin packets of them in solutions. So, the values of the specific surface area of dispersions of montmorillonite samples in solutions are much higher than of air-dried samples (maximum crystallographic value of SSA are $\sim 750-780 \mathrm{~m}^{2} / \mathrm{g}$ [41]). Therefore, the values of the sorption of uranium on both the pristine and modified minerals are the average values between those for kaolinite and montmorillonite (see Figures 7 and 8).

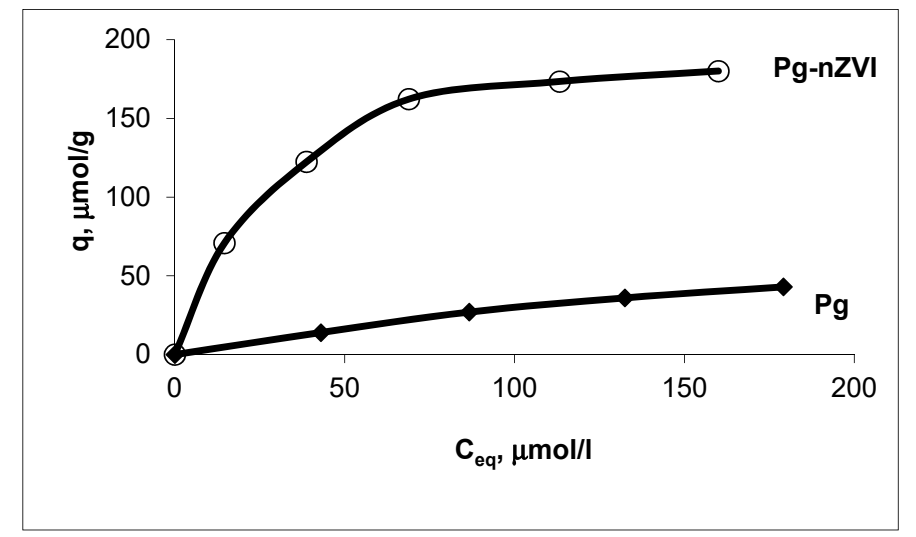

Figure 7. Sorption isotherms of U(VI) ions on pristine paligorskite and paligorskite-nZVI.

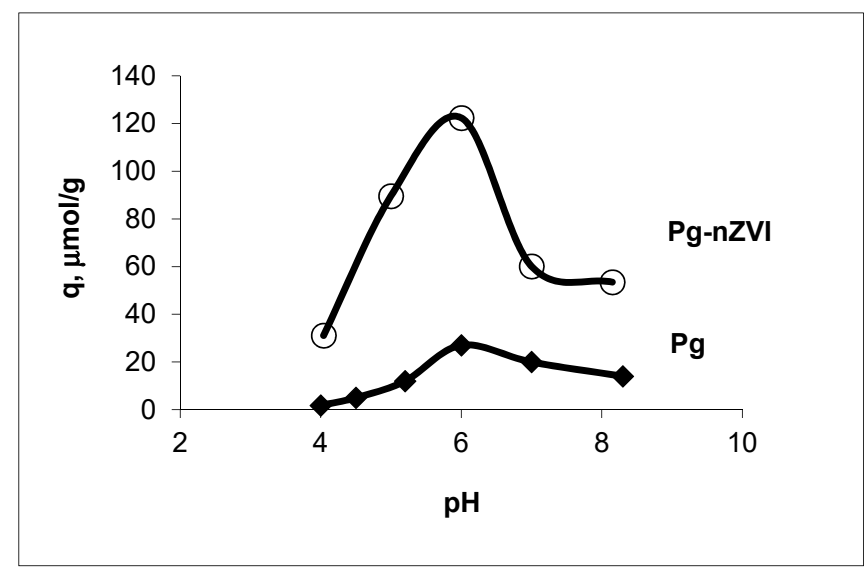

Figure 8. Sorption of $\mathrm{U}(\mathrm{VI})$ ions on pristine paligorskite and paligorskite-nZVI as a function of $\mathrm{pH}$.

When considering the sorption processes in mineralized waters, it is important to analyze the forms in which uranium exists under these conditions. Medusa software, which is widely used in analytical practice, was used for calculations [49]. The main solid phases of uranium in aqueous systems are insoluble hydrates $\mathrm{UO}_{3} \cdot \mathrm{H}_{2} \mathrm{O}$ or $\mathrm{UO}_{2}(\mathrm{OH})_{2}\left(\lg K_{s p}=-20.34--23.5\right)[47,50]$ and carbonate $\mathrm{UO}_{2} \mathrm{CO}_{3}\left(\lg K_{s p}=-13.21--14.26\right)$ [51]. At the same time, sulfate, carbonate, phosphate and nitrate complexes of uranium may be the main species in water.The composition of main anions of underground mineralized water near the liquid waste storage facility for hydrometallurgical processing uranium ores at the Centre of Ukrainian Uranium Industry (Zhovti Vody)are: $\mathrm{HCO}_{3}^{-}-450$; $\mathrm{Cl}^{-}-180 ; \mathrm{SO}_{4}^{2-}-2830 ; \mathrm{NO}_{3}^{-}-130 \mathrm{mg} / \mathrm{L}$. The high affinity of uranyl ions to the nitrate is known, but the content of nitrate-ions in Zhovti Vody mineralized water is much smaller thanthe content of carbonate-ions and sulfate-ions. Therefore, we did not include nitrate-ions complexes in the speciation calculations. Zhovti Vody-mineralized waters, even with a sufficiently high content of uranium in them, are characterized by almost complete binding of uranium to sulfate complexes $\mathrm{UO}_{2} \mathrm{SO}_{4}$ 
and $\mathrm{UO}_{2}\left(\mathrm{SO}_{4}\right)_{2}^{2-}$ in the acidic area, as well as in carbonate complexes $\mathrm{UO}_{2} \mathrm{CO}_{3}, \mathrm{UO}_{2}\left(\mathrm{CO}_{3}\right)_{2}^{2-}$ and $\mathrm{UO}_{2}\left(\mathrm{CO}_{3}\right)_{3}^{4-}$ in neutral and alkaline areas (see Figure 9).

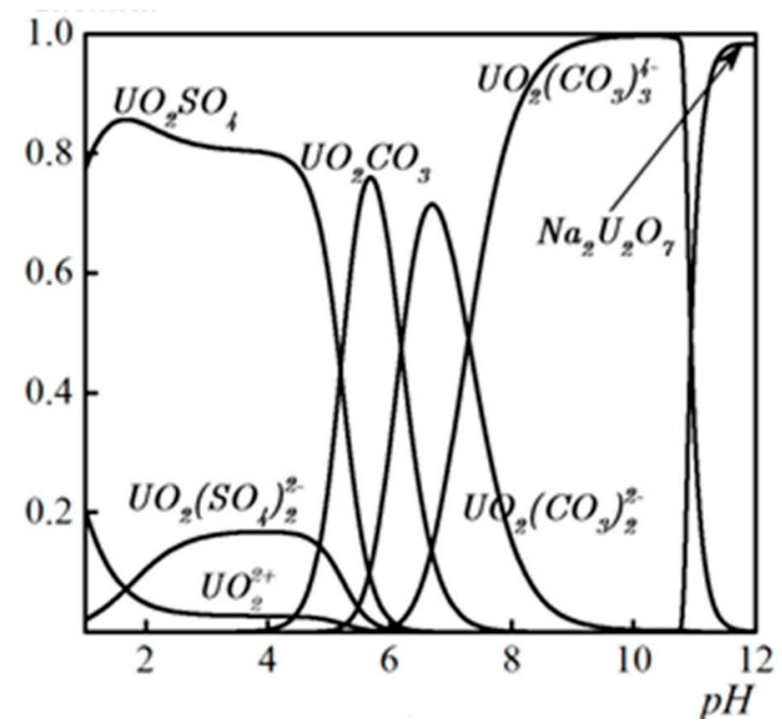

Figure 9. U(VI) speciation in mineralized groundwater.

Sorption processes in mineralized waters were studied using montmorillonite and paligorskite. The $\mathrm{pH}$ dependence curves of uranium sorption values have a characteristic form for both types of clays with a maximum in the $\mathrm{pH}$ area of 5-7 (Figure 10).

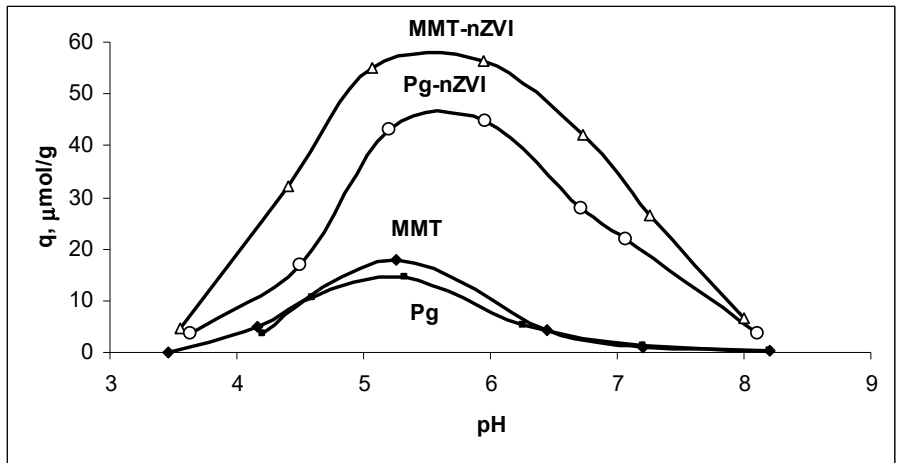

Figure 10. Sorption of U(VI) ions on pristine and nZVI-modified montmorillonite and palygorskite from mineralized waters as a function of $\mathrm{pH}$.

Sorption of uranium complexes occurs primarily due to the exchange of hydroxyl ions of the hydroxide film on the surface of nanoscale iron particles:

$$
\begin{aligned}
& \mathrm{M}-(\mathrm{OH})_{\mathrm{n}}+\mathrm{UO}_{2}\left(\mathrm{SO}_{4}\right)_{2}{ }^{2-} \rightarrow \mathrm{M}-(\mathrm{OH})_{\mathrm{n}-2} \mathrm{UO}_{2}\left(\mathrm{SO}_{4}\right)_{2}+2 \mathrm{OH}^{-} \\
& \mathrm{M}-(\mathrm{OH})_{\mathrm{n}}+\mathrm{UO}_{2}\left(\mathrm{CO}_{3}\right)_{2}{ }^{2-} \rightarrow \mathrm{M}-(\mathrm{OH})_{\mathrm{n}-2} \mathrm{UO}_{2}\left(\mathrm{CO}_{3}\right)_{2}+2 \mathrm{OH}^{-}
\end{aligned}
$$

When considering the mechanism of sorption of uranium compounds on the surface of clays, especially of rather high concentration of uranium, the possibility of precipitation of sparingly soluble hydroxides and others(hexavalent uranium compounds schoepite, carnotite, tyuyamunite, etc. [52]) cannot be ruled out. In mineralized waters, in contrast to diluted waters, the solubility of insoluble salts of uranium is significantly increased. Therefore, at concentrations of salts corresponding to those in mineralized waters from 3-5 to 10-20 g/L [52], the precipitation of uranium solid phases is not expected and the most probable mechanism of uranium binding is only the sorption mechanism. 
Sorption isotherms of uranium from mineralized waters were obtained at $\mathrm{pH}$ 7.2, which corresponds to the $\mathrm{pH}$ value of real groundwater (Figure 11).

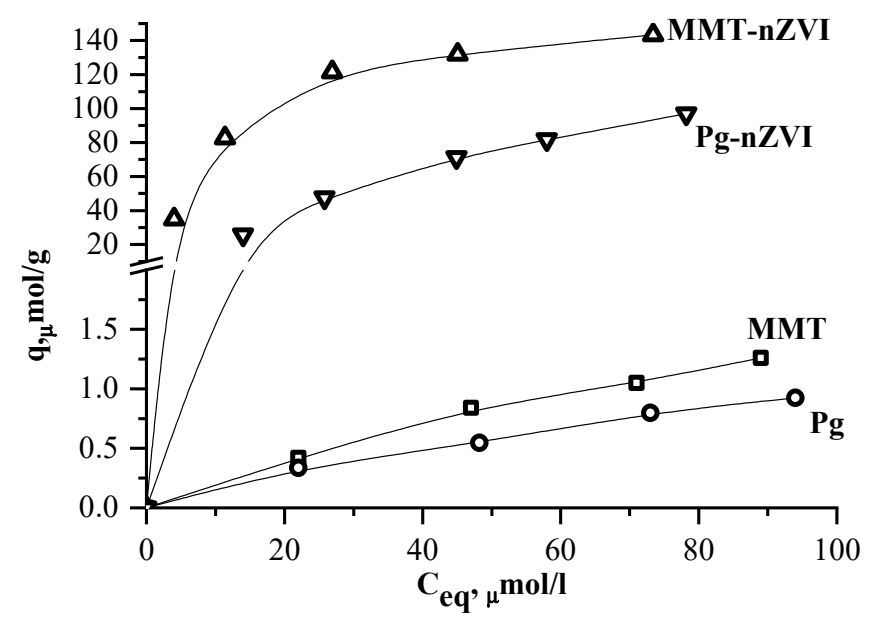

Figure 11. Sorption isotherms of $\mathrm{U}(\mathrm{VI})$ ions on pristine and nZVI-modified montmorillonite and palygorskite from mineralized waters.

Sorption isotherms were analyzed using Langmuir and Freundlich equations. The results of the calculations of the corresponding coefficients are shown in Table 2.

Table 2. Langmuir and Freundlich parameters for the adsorption of uranyl ions onto pristine and nZVI-modified minerals.

\begin{tabular}{|c|c|c|c|c|}
\hline Sample & MMT & \multicolumn{2}{|c|}{ MMT-nZVI Pg } & Pg-nZVI \\
\hline \multicolumn{5}{|l|}{ Langmuir } \\
\hline $\mathrm{a} \infty, \mu \mathrm{mol} \mathrm{g}^{-1}$ & 125 & 452 & 59 & 325 \\
\hline $\mathrm{K}_{\mathrm{L}}, \mathrm{L} \mu \mathrm{mol}^{-1}$ & 0.0084 & 0.1093 & 0.0096 & 0.1221 \\
\hline $\mathrm{R}^{2}$ & 0.956 & 0.964 & 0.975 & 0.938 \\
\hline \multicolumn{5}{|l|}{ Freundlich } \\
\hline $\mathbf{K}_{\mathbf{F}}$ & 5.3 & 92.0 & 3.2 & 116.5 \\
\hline $1 / n$ & 1.97 & 3.28 & 2.13 & 3.35 \\
\hline $\mathbf{R}^{2}$ & 0.887 & 0.825 & 0.850 & 0.892 \\
\hline
\end{tabular}

The obtained isotherms are well described by the equation of monomolecular Langmuir sorption (correlation coefficient $\mathrm{R}^{2}=0.968-0.996$ ) which assumes the energy homogeneity of the active centres accordingly. For the empirical Freundlich equation, which is suitable mainly for describing the starting areas of isotherms, the correlation coefficient is lower $\left(R^{2}=0.934-0.991\right)$.

\section{Conclusions}

Thus, different in structure clays are effective cheap matrices for obtaining efficient sorption materials based on zero valence iron for purification of uranium-contaminated surface and mineralized groundwater, which is typical for areas of uranium ore mining and processing.In terms of sorption capacity, the composite samples form a sequence: montmorillonite-nZVI > paligorskite-nZVI > kaolinite-nZVI, which corresponds to a decrease in the specific surface area of the pristine clay minerals.

Removal of U(VI) from mineralized waters occurs primarily due to the exchange of hydroxyl ions of the hydroxide film on the surface of nanoscale iron particles by uranium sulfate and carbonate complexes.

Another possible mechanism of immobilization of uranium compounds is the reduction of uranium (VI) to uranium (IV) by electron transfer from the volume of nZVI particles through a 
hydroxide film to their surface with the formation and deposition of much less soluble compounds of the latter.However, it is necessary to specify the main reactions in the removal of uranium by immobilized ZVI for its further practical applications.

Author Contributions: Conceptualization, B.K.; methodology, I.K. and V.T.; validation, B.K. and I.K.; formal analysis, I.K.; investigation, I.K., V.T.; writing-original draft preparation, B.K., S.U.; writing-review \& editing, B.K. All authors have read and agreed to the published version of the manuscript.

Funding: This research received no external funding.

Acknowledgments: Author is grateful to the staff of Institute for Sorption and Problems of Endoecology and Igor Sikorsky Kyiv Polytechnic Institute for the help and support.

Conflicts of Interest: The authors declare no conflict of interest.

\section{References}

1. Merkel, B.; Schipek, M. (Eds.) The New Uranium Mining Boom; Springer: Berlin/Heidelberg, Germany, 2011; 848p, ISBN 978-3-642-22122-4.

2. Liu, B.; Peng, T.; Hong-Juan, S.; Yue, H. Release behavior of uranium in uranium mill tailings under environmental conditions. J. Environ. Radioact. 2017, 171, 160-168. [CrossRef] [PubMed]

3. Selvakumar, R.; Ramadoss, G.; Menon, M.P.; Rajendran, K.; Thavamani, P.; Naidu, R.; Megharaj, M. Challenges and complexities in remediation of uranium contaminated soils: A review. J. Environ. Radioact. 2018, 192, 592-603. [CrossRef] [PubMed]

4. Yin, M.; Sun, J.; Chen, Y.; Wang, J.; Shang, J.; Belshaw, N.; Shen, C.; Liu, J.; Li, H.; Linghu, W.; et al. Mechanism of uranium release from uranium mill tailings under long-term exposure to simulated acid rain: Geochemical evidence and environmental implication. Environ. Pollut. 2019, 244, 174-181. [CrossRef] [PubMed]

5. Neiva, A.; Antunes, I.; Carvalho, P.C.S.; Santos, A. Uranium and arsenic contamination in the former Mondego Sul uranium mine area, Central Portugal. J. Geochem. Explor. 2016, 162, 1-15. [CrossRef]

6. Bernhard, G.; Geipel, G.; Brendler, V.; Nitsche, H. Uranium speciation in waters of different uranium mining areas. J. Alloy. Compd. 1998, 201-205. [CrossRef]

7. Mühr-Ebert, E.; Wagner, F.; Walther, C. Speciation of uranium: Compilation of a thermodynamic database and its experimental evaluation using different analytical techniques. Appl. Geochem. 2019, 100, $213-222$. [CrossRef]

8. Myasoyedova, G.V.; Nikashyna, V.A. Sorption materials fort he extraction of radionuclides from aqueous media. Russ. Chem. J. 2006, 50, 55-63.

9. Krajňák, A.; Viglašová, E.; Galamboš, M.; Krivosudský, L. Application of HDTMA-intercalated bentonites in water waste treatment for U(VI) removal. J. Radioanal. Nucl. Chem. 2017, 314, 2489-2499. [CrossRef]

10. Krajnák, A.; Viglašová, E.; Galamboš, M.; Krivosudský, L. Kinetics, thermodynamics and isotherm parameters of uranium(VI) adsorption on natural and HDTMA-intercalated bentonite and zeolite. Desalin. Water Treat. 2018, 127, 272-281. [CrossRef]

11. Kornilovych, B.; Wireman, M.; Caruso, B.; Koshik, Y.; Pavlenko, V.; Tobilko, V. The use of permeable reactive barrier against contaminated groundwater in Ukraine. Central Eur. J. Occup. Environ. Med. 2009, 15, 73-85.

12. Interstate Technology \& Regulatory Council. Permeable Reactive Barriers: Technology Update. PRB-5; Interstate Technology \& Regulatory Council, PRB; Technology Update Team: Washington, DC, USA, 2011; Available online: www.itrcweb.org (accessed on 17 September 2020).

13. Zhang, W.-X. Nanoscale Iron Particles for Environmental Remediation: An Overview. J. Nanoparticle Res. 2003, 5, 323-332. [CrossRef]

14. Fu, F.; Dionysiou, D.; Liu, H. The use of zero-valent iron for groundwater remediation and wastewater treatment: A review. J. Hazard. Mater. 2014, 267, 194-205. [CrossRef]

15. Zou, Y.; Wang, X.; Khan, A.; Wang, P.; Liu, Y.; Alsaedi, A.; Hayat, T.; Wang, X. Environmental Remediation and Application of Nanoscale Zero-Valent Iron and Its Composites for the Removal of Heavy Metal Ions: A Review. Environ. Sci. Technol. 2016, 50, 7290-7304. [CrossRef] [PubMed]

16. Chen, A.; Shang, C.; Shao, J.; Zhang, J.; Huang, H. The application of iron-based technologies in uranium remediation: A review. Sci. Total. Environ. 2017, 575, 1291-1306. [CrossRef] 
17. Jing, C.; Li, Y.; Landsberger, S. Review of soluble uranium removal by nanoscale zero valent iron. J. Environ. Radioact. 2016, 164, 65-72. [CrossRef] [PubMed]

18. Jiang, D.; Zeng, G.; Huang, D.; Chen, M.; Zhang, C.; Huang, C.; Wan, J. Remediation of contaminated soils by enhanced nanoscale zero valent iron. Environ. Res. 2018, 163, 217-227. [CrossRef]

19. Tosco, T.; Papini, M.P.; Viggi, C.C.; Sethi, R. Nanoscale zerovalent iron particles for groundwater remediation: A review. J. Clean. Prod. 2014, 77, 10-21. [CrossRef]

20. Zhao, X.; Liu, W.; Cai, Z.; Han, B.; Qian, T.; Zhao, D. An overview of preparation and applications of stabilized zero-valent iron nanoparticles for soil and groundwater remediation. Water Res. 2016, 100, 245-266. [CrossRef] [PubMed]

21. Trujillo-Reyes, J.; Peralta-Videa, J.; Gardea-Torresdey, J.L. Supported and unsupported nanomaterials for water and soil remediation: Are they a useful solution for worldwide pollution? J. Hazard. Mater. 2014, 280, 487-503. [CrossRef]

22. Liu, Z.; Zhang, F.; Hoekman, S.K.; Liu, T.; Gai, C.; Peng, N. Homogeneously Dispersed Zerovalent Iron Nanoparticles Supported on Hydrochar-Derived Porous Carbon: Simple, in Situ Synthesis and Use for Dechlorination of PCBs. ACS Sustain. Chem. Eng. 2016, 4, 3261-3267. [CrossRef]

23. Petala, E.; Dimos, K.; Douvalis, A.; Bakas, T.; Tucek, J.; Zbořil, R.; Karakassides, M.A. Nanoscale zero-valent iron supported on mesoporous silica: Characterization and reactivity for $\mathrm{Cr}(\mathrm{VI})$ removal from aqueous solution. J. Hazard. Mater. 2013, 261, 295-306. [CrossRef] [PubMed]

24. Sun, Z.; Zheng, S.; Ayoko, G.A.; Frost, R.L.; Xi, Y. Degradation of simazine from aqueous solutions by diatomite-supported nanosized zero-valent iron composite materials. J. Hazard. Mater. 2013, 263, 768-777. [CrossRef]

25. Yua, S.; Wangab, X.; Liua, Y.; Chena, Z.; Wua, Y.; Liua, Y.; Panga, H.; Songc, G.; Chen, J.; Wang, X. Efficient removal of uranium(VI) by layered double hydroxides supported nanoscale zero-valent iron: A combined experimental and spectroscopic studies. Chem. Eng. J. 2019, 365, 51-59. [CrossRef]

26. Ding, C.; Cheng, W.; Nie, X.; Yi, F.; Xiang, S.; Asiri, A.M.; Marwani, H.M. Reactivity of carbonized fungi supported nanoscale zero-valent iron toward U(VI) influenced by naturally occurring ions. J. Ind. Eng. Chem. 2018, 61, 236-243. [CrossRef]

27. Lv, X.; Xue, X.; Jiang, G.; Wu, D.; Sheng, T.; Zhou, H.; Xinhua, X. Nanoscale Zero-Valent Iron (nZVI) assembled on magnetic Fe3O4/graphene for Chromium (VI) removal from aqueous solution. J. Colloid Interface Sci. 2014, 417, 51-59. [CrossRef] [PubMed]

28. Tan, L.; Wang, Y.; Liu, Q.; Wang, J.; Jing, X.; Liu, L.; Liu, J.; Song, D. Enhanced adsorption of uranium (VI) using a three-dimensional layered double hydroxide/graphene hybrid material. Chem. Eng. J. 2015, 259, 752-760. [CrossRef]

29. Kurniawan, T.A.; Chan, G.Y.; Lo, W.-H.; Babel, S. Comparisons of low-cost adsorbents for treating wastewaters laden with heavy metals. Sci. Total. Environ. 2006, 366, 409-426. [CrossRef]

30. Misaelides, P. Clay minerals and zeolites for radioactive waste immobilization and containment. Modif. Clay Zeolite Nanocomposite Mater. 2019, 243-274. [CrossRef]

31. Ezzatahmadi, N.; Ayoko, G.A.; Millar, G.J.; Speight, R.; Yan, C.; Li, J.; Li, S.; Zhu, J.; Xi, Y. Clay-supported nanoscale zero-valent iron composite materials for the remediation of contaminated aqueous solutions: A review. Chem. Eng. J. 2017, 312, 336-350. [CrossRef]

32. Üzüm, Ç.; Shahwan, T.; Eroğlu, A.E.; Hallam, K.R.; Scott, T.B.; Lieberwirth, I. Synthesis and characterization of kaolinite-supported zero-valent iron nanoparticles and their application for the removal of aqueous $\mathrm{Cu}^{2+}$ and $\mathrm{Co}^{2+}$ ions. Appl. Clay Sci. 2009, 43, 172-181. [CrossRef]

33. Shahwan, T.; Üzüm, Ç.; Eroğlu, A.E.; Lieberwirth, I. Synthesis and characterization of bentonite/iron nanoparticles and their application as adsorbent of cobalt ions. Appl. Clay Sci. 2010, 47, 257-262. [CrossRef]

34. Bhowmick, S.; Chakrabarti, S.; Mondal, P.; Van Renterghem, W.; Berghe, S.V.D.; Roman-Ross, G.; Chatterjee, D.; Iglesias, M. Montmorillonite-supported nanoscale zero-valent iron for removal of arsenic from aqueous solution: Kinetics and mechanism. Chem. Eng. J. 2014, 243, 14-23. [CrossRef]

35. Jing, C.; Landsberger, S.; Li, Y. The application of illite supported nanoscale zero valent iron for the treatment of uranium contaminated groundwater. J. Environ. Radioact. 2017, 175, 1-6. [CrossRef]

36. Zhdanyuk, N.V.; Kovalchuk, I.A.; Kornilovych, B.Y. Sorption of uranium (VI) and cobalt (II) ions by iron-containing nanocomposites based on palygorskite. Surface Chem. Phys. Techn. 2019, 10, 48-58. [CrossRef] 
37. Rouquerol, F.; Rouquerol, J.; Sing, K.S.W.; Llewellyn, P.; Maurin, G. Adsorption by Powders and Porous Solids; Elsevier: Amsterdam, The Netherlands, 2014; ISBN 9780080970356.

38. Shi, L.-N.; Lin, Y.-M.; Zhang, X.; Chen, Z.-L. Synthesis, characterization and kinetics of bentonite supported nZVI for the removal of $\mathrm{Cr}(\mathrm{VI})$ from aqueous solution. Chem. Eng. J. 2011, 171, 612-617. [CrossRef]

39. Tobilko, V.Y.; Kornilovych, B.Y. Synthethis and sorption properties of composite materials based on nanoscale Fe. East. Eur. J. Enterp. Technol. 2015, 4, 22-27.

40. Kornilovych, B.; Wireman, M.; Ubaldini, S.; Guglietta, D.; Koshik, Y.; Caruso, B.; Kovalchuk, I. Uranium Removal from Groundwater by Permeable Reactive Barrier with Zero-Valent Iron and Organic Carbon Mixtures: Laboratory and Field Studies. Metals 2018, 8, 408. [CrossRef]

41. Bergaya, F.; Theng, B.K.; Lagaly, G. Handbook of Clay Science; Elsevier: London, UK, 2006; 1246p, ISBN 9780080441832.

42. Sposito, G. The Surface Chemistry of Soils; Oxford University Press: Oxford, UK, 1984; 344p, ISBN 9780195313697.

43. Crane, R.; Pullin, H.; Scott, T. The influence of calcium, sodium and bicarbonate on the uptake of uranium onto nanoscale zero-valent iron particles. Chem. Eng. J. 2015, 277, 252-259. [CrossRef]

44. Chekli, L.; Bayatsarmadi, B.; Sekine, R.; Sarkar, B.; Shen, A.M.; Scheckel, K.G.; Skinner, W.; Naidu, R.; Shon, H.K.; Lombi, E.; et al. Analytical characterisation of nanoscale zero-valent iron: A methodological review. Anal. Chim. Acta 2016, 903, 13-35. [CrossRef]

45. Sheng, G.; Shao, X.; Li, Y.; Li, J.; Dong, H.; Cheng, W.; Gao, X.; Huang, Y. Enhanced Removal of Uranium(VI) by Nanoscale Zerovalent Iron Supported on Na-Bentonite and an Investigation of Mechanism. J. Phys. Chem. A 2014, 118, 2952-2958. [CrossRef]

46. Kornilovich, B.Y.; Pshinko, G.N.; Bogolepov, A.A. Effects of EDTA and NTA on sorption of U(VI) on the clay fraction of soil. Radiochemistry 2006, 48, 584-588. [CrossRef]

47. Altmaier, M.; Yalçıntaş, E.; Gaona, X.; Neck, V.; Müller, R.; Schlieker, M.; Fanghänel, T. Solubility of U(VI) in chloride solutions. I. The stable oxides/hydroxides in $\mathrm{NaCl}$ systems, solubility products, hydrolysis constants and SIT coefficients. J. Chem. Thermodyn. 2017, 114, 2-13. [CrossRef]

48. Galan, E.; Singer, A. (Eds.) Developments in Palygorskite-Sepiolite Research; Galan, E.; Singer, A. (Eds.) Elsevier: Amsterdam, The Netherlands, 2011; Volume 3, 520p, ISBN 9780444536075.

49. Puigdomènech, I.; Colas, E.; Glive, M.; Campos, I.; Garcia, D. A tool to draw chemical equilibrium diagrams using SIT: Applications to geochemical systems and radionuclide solubility. MRS Online Proc. Libr. Arch. 2014, 1665, 111-116. [CrossRef]

50. Fujiwara, K.; Yamana, H.; Fujii, T.; Kawamoto, K.; Sasaki, T.; Moriyama, H. Solubility Product of Hexavalent Uranium Hydrous Oxide. J. Nucl. Sci. Technol. 2005, 42, 289-294. [CrossRef]

51. Kramer-Schnabel, U.; Bischoff, H.; Xi, R.H.; Marx, G. Solubility Products and Complex Formation Equilibria in the Systems Uranyl Hydroxide and Uranyl Carbonate at $25^{\circ} \mathrm{C}$ and $\mathrm{I}=0.1 \mathrm{M}$. Radiochim. Acta 1992, 56, 183-188. [CrossRef]

52. Prentice Hall; Langmuir, D. Aqueous Environmental Geochemistry; Prentice Hall: Upper Saddle River, NJ, USA, 1997; 600p, ISBN 13-978-0023674129.

Publisher's Note: MDPI stays neutral with regard to jurisdictional claims in published maps and institutional affiliations.

(C) 2020 by the authors. Licensee MDPI, Basel, Switzerland. This article is an open access article distributed under the terms and conditions of the Creative Commons Attribution (CC BY) license (http://creativecommons.org/licenses/by/4.0/). 